Revista Eletrônica de Direito Processual - REDP. Volume 16. Julho a dezembro de 2015

Periódico Semestral da Pós-Graduação Stricto Sensu em Direito Processual da UERJ

Patrono: José Carlos Barbosa Moreira. ISSN 1982-7636. pp. 58-76 http://www.e-publicacoes.uerj.br/index.php/redp/index

\title{
NEGÓCIOS PROCESSUAIS RELATIVOS A HONORÁRIOS ADVOCATÍCIOS ${ }^{1}$
}

PROCEDURAL SETTLEMENTS CONCERNING LAWYER'S REMUNERATION

Bruno Garcia Redondo

Doutorando e Mestre em Direito Processual Civil pela PUC-SP.

Advogado.

http://www.facebook.com/profgarciaredondo.

bruno@garcia-redondo.com

Julio Guilherme Müller

Doutorando em Direito Processual Civil pela PUC-SP. Mestre em Direito pela Universidade Federal do Paraná. Especialista em Direito Processual Civil pela Universidade Federal de Santa Catarina. Advogado. julio@advogadosc.com.br

RESUMO: Este ensaio examina o alcance e os limites dos negócios jurídicos processuais que envolvam honorários advocatícios.

PALAVRAS-CHAVE: Honorários advocatícios — Honorários de sucumbência — Negócios jurídicos processuais.

RIASSUNTO: Questo studio cerca di esaminare i limiti del negozio processuale su onorari di difesa (remunerazione giudiziaria dell'avvocato).

PAROLE CHIAVE: Onorari di difesa - Negozio processuale.

\footnotetext{
${ }^{1}$ Artigo recebido em 22/06/2015 e aprovado em 17/11/2015.
} 
Revista Eletrônica de Direito Processual - REDP. Volume 16. Julho a dezembro de 2015

Periódico Semestral da Pós-Graduação Stricto Sensu em Direito Processual da UERJ

Patrono: José Carlos Barbosa Moreira. ISSN 1982-7636. pp. 58-76

http://www.e-publicacoes.uerj.br/index.php/redp/index

SUMÁRIO: 1. Novo CPC e a cláusula geral de atipicidade negócio processual - 2. Objeto e limites dos negócios processuais atípicos -3 . Validade dos negócios processuais atípicos: relação entre os regimes do $\mathrm{CPC}$ e do $\mathrm{CC}$ - 4. Eficácia dos negócios processuais atípicos - 5 . Convenções das partes sobre honorários advocatícios - 6. Referências bibliográficas.

\section{Novo CPC e a cláusula geral de atipicidade negócio processual}

Em 16 de março de 2015 foi sancionado o novo Código de Processo Civil, fruto de intenso trabalho iniciado por comissão de juristas designada pelo Senado Federal em 2009, continuado por outras comissões designadas pela Câmara dos Deputados e pelo Senado Federal (no retorno do Projeto à Casa iniciadora) e que contou com maciça participação de professores de Direito (em Fóruns temáticos) e da própria sociedade (em Audiências Públicas e por e-mail).

A Lei 13.105/2015, que instituiu a novel codificação, apresenta várias modificações e inovações com louvável potencial de utilidade e efetividade. Comparadas ao anterior Código de 1973, as alterações guardam nítido objetivo modernizar o procedimento e adequá-lo às necessidades sociais de nosso tempo.

Há mecanismos em prol da coerência, da estabilidade e da isonomia, tais como a valorização de precedentes, a eficácia vinculante de determinadas decisões, a criação do incidente de resolução de demandas repetitivas e a ampliação do cabimento da reclamação. Há dispositivos também voltados à qualidade da prestação jurisdicional, como se observa do aprimoramento dos textos que regulam garantias constitucionais (como a fundamentação das decisões, o contraditório e a ampla defesa) e que conferem primazia às questões de mérito (mediante eliminação de grande parte de indevidos obstáculos processuais que impediam o exame da matéria de fundo dos recursos, movimento que se denominou "jurisprudência defensiva").

Interessa ao presente trabalho, contudo, aquelas modificações em torno das novas dimensões da autonomia da vontade das partes no que tange às situações processuais, bem como a possibilidade de convenção a respeito dos honorários advocatícios de sucumbência e o seu arbitramento judicial.

É possível afirmar que a partir de meados do século XIX, mais especificamente por 
Revista Eletrônica de Direito Processual - REDP. Volume 16. Julho a dezembro de 2015

Periódico Semestral da Pós-Graduação Stricto Sensu em Direito Processual da UERJ

Patrono: José Carlos Barbosa Moreira. ISSN 1982-7636. pp. 58-76

http://www.e-publicacoes.uerj.br/index.php/redp/index

força dos estudos de Oskar Bülow² sobre o processo como relação jurídica (processual, entre as partes e o Estado) diversa da relação de direito material, surgiram estudos diferenciando os planos do ordenamento jurídico (material e processual) e reconhecendo o Direito Processual como ramo do Direito Público, cujas normas seriam erga omnes e de aplicação cogente.

A autonomia científica do Direito Processual, aliada a diversos outros fatores históricos (inclusive políticos e sociais) que culminaram com o entendimento de que o Brasil teria adotado o modelo inquisitivo (inquisitorial ou não adversarial) de processo (pelo qual o órgão jurisdicional assume a função de protagonista da relação processual), levou a uma publicização cada vez maior do Direito Processual Civil. Por essa razão, a autonomia da vontade das partes (para convencionarem sobre suas situações processuais) encontrou, como regra geral, espaço bastante limitado sob a égide do Código de 1973.

Chiovenda afirmava que "não existe, pois, um processo convencional, quer dizer, ao juiz e às partes não é permitido governar arbitrariamente o processo; mas em certos casos é livre às partes desatenderem a uma norma processual, já por acordo expresso ou tácito, já deixando de assinalar-lhe a observância. Se as partes gozam ou não dessa liberdade, deve ressaltar dos termos expressos da lei ou do escopo da norma determinada: na dúvida, as normas processuais devem reputar-se cogentes. ${ }^{\prime 3}$.

Dito diploma estabeleceu número reduzido de convenções processuais típicas, regulando apenas determinadas situações processuais. Como exemplos de convenções típicas naquele Código, tem-se a admissibilidade de acordos sobre o foro da demanda (critério territorial relativo de competência), o ônus da prova, o adiamento da audiência de instrução e julgamento e a fixação de prazos dilatórios.

Não obstante a regulamentação expressa dessas hipóteses, a própria natureza jurídica de tais convenções era controvertida na doutrina. O entendimento que prevaleceu, à luz do CPC/1973, era contrário à existência da categoria negócio jurídico processual ${ }^{4}$, baseado na ótica

\footnotetext{
${ }^{2}$ BÜLOW, Oskar. Teoria das exceções e dos pressupostos processuais. 2. ed. (trad. bras. Ricardo Rodrigues Gama). São Paulo: LZN, 2005.

${ }^{3}$ CHIOVENDA, Giuseppe. Instituições de direito processual civil. São Paulo: Bookseller. v. 1, p. 99.

${ }^{4}$ Recusando, categoricamente, a figura dos negócios jurídicos processuais sobre a égide do CPC/1973, por todos, DINAMARCO, Cândido Rangel. Instituições de direito processual civil. 6. ed. São Paulo: Malheiros, 2009. v. 2, p. 484-485; e CÂMARA, Alexandre Freitas. Lições de direito processual civil. 23. ed. São Paulo: Atlas, 2012. v. 1, p. 274.
} 
Revista Eletrônica de Direito Processual - REDP. Volume 16. Julho a dezembro de 2015

Periódico Semestral da Pós-Graduação Stricto Sensu em Direito Processual da UERJ

Patrono: José Carlos Barbosa Moreira. ISSN 1982-7636. pp. 58-76

http://www.e-publicacoes.uerj.br/index.php/redp/index

de que a vontade não teria qualquer relevância na produção de efeitos pelo ato processual. $\mathrm{O}$ sentido juridicamente relevante do ato processual seria objetivo, sem qualquer relação com elementos estranhos à declaração. A vontade das partes seria, pois, irrelevante na determinação dos efeitos dos atos processuais. Aquelas situações processuais anteriormente referidas, para grande parte da doutrina, tinham natureza de meros atos processuais, e não de negócios processuais.

Dentro do universo reduzido de estudiosos que reconheciam a figura dos negócios processuais, prevaleceu a ideia de que seriam cabíveis somente as hipóteses típicas, isto é, aquelas regulamentadas especificamente na $1 \mathrm{i}^{5}$. $\mathrm{O}$ entendimento ali predominante foi o de que o Código de 1973 teria sido silente quanto à possibilidade de celebração de convenções atípicas pelas partes (sem prévia regulamentação específica), levando à conclusão no sentido de sua impossibilidade, não obstante, curiosamente, o art. 158 guardar um significativo potencial de interpretação no sentido de ali estar consagrada, implicitamente, uma cláusula geral de atipicidade de negócios jurídicos processuais ${ }^{6}$. Esse, porém, não foi o entendimento que prevaleceu na ocasião.

Por essa razão, foram escassos os estudos brasileiros sobre as convenções atípicas das partes em matéria processual, sendo importante destacar e homenagear, dentre eles, os de autoria de Barbosa Moreira ${ }^{7}$ e Leonardo Greco ${ }^{8}$. Mais recentemente, começaram a surgir estudos destinados a criticar o dogma da irrelevância da vontade no processo, que impedia a construção de uma adequada teoria sobre os atos processuais e, por isso, não permitia um tratamento satisfatório sobre sua interpretação nem sobre os vícios de vontade nos atos processuais ${ }^{9}$.

Buscando a quebra desse paradigma exacerbadamente publicista e a diminuição do

\footnotetext{
${ }^{5}$ Por todos, MARTINS, Sandro Gilbert. Processo, procedimento e ato processual: o plano da eficácia. Rio de Janeiro: Elsevier, 2012, p. 34-35.

${ }^{6} \mathrm{Na}$ Dissertação de Mestrado de um dos autores do presente ensaio, defendida em 2013, foi abordado, com maior profundidade o potencial que poderia ter sido dado ao art. 158 do CPC/1973, com o reconhecimento de uma consagração de uma (implícita) cláusula geral de atipicidade de negócios processuais: REDONDO, Bruno Garcia. Flexibilização do procedimento pelo juiz e pelas partes no Direito Processual Civil brasileiro. Dissertação de Mestrado. São Paulo: PUC-SP, 2013.

${ }^{7}$ MOREIRA, José Carlos Barbosa. Convenções das partes sobre matéria processual. In: MOREIRA, José Carlos Barbosa. Temas de direito processual: terceira série. São Paulo: São Paulo: Saraiva, 1994, p. 91-98.

${ }^{8}$ Sobre o tema: GRECO, Leonardo. Os atos de disposição processual: primeiras reflexões. Revista Eletrônica de Direito Processual, Rio de Janeiro: UERJ, a. 1, v. 1, out.-dez. 2007, p. 07-28.

${ }^{9}$ NOGUEIRA, Pedro Henrique Pedrosa. Negócios jurídicos processuais: análise dos provimentos judiciais como atos negociais. Tese de Doutorado. Salvador: UFBA, 2011.
} 
Revista Eletrônica de Direito Processual - REDP. Volume 16. Julho a dezembro de 2015

Periódico Semestral da Pós-Graduação Stricto Sensu em Direito Processual da UERJ

Patrono: José Carlos Barbosa Moreira. ISSN 1982-7636. pp. 58-76

http://www.e-publicacoes.uerj.br/index.php/redp/index

excessivo protagonismo judicial, o Código de Processo Civil brasileiro de 2015 (Lei

13.105/2015, publicada em 17.03.2015, com vacatio legis de 01 ano) parte de premissa diversa, ao se basear no princípio da adequação (especialmente a negocial, isto é, pelas partes), e instituir um modelo de processo claramente cooperativo.

O Código de 2015 prevê, de início, maior número de hipóteses de negócios processuais típicos (com regulamentação legal específica), permitindo, às partes, maiores poderes para condução do processo (v.g., escolha da pessoa do perito, fixação de calendário processual, saneamento cooperativo/compartilhado).

Quebrando paradigmas em relação ao Código de 1973, foi inserida proposta — durante a tramitação legislativa do Projeto que deu origem ao novo Código —, na Câmara dos Deputados (posteriormente mantida pelo Senado Federal e pela Presidência da República), no sentido da consagração de uma norma que passasse a permitir, às partes, a celebração de convenções, de maneira mais ampla e autônoma (em relação ao juiz), antes ou durante o curso do processo, a respeito de seus ônus, poderes, faculdades e deveres processuais, bem como a estipulação de mudanças no procedimento para ajustá-lo às especificidades da causa ou às necessidades do direito material.

Dito dispositivo tornou-se o art. 190 do Código de $2015^{10}$, o qual, no que interessa ao objeto do presente ensaio, consagrou verdadeira cláusula geral de atipicidade de negócios processuais $^{11-12}$, sendo ampla a liberdade das partes para celebração de convenções processuais.

A autorização legal é atípica porque inexiste prévia estipulação das adequações que podem ser efetuadas no procedimento, como também não há específica identificação do objeto

\footnotetext{
10 “Art. 190. Versando o processo sobre direitos que admitam autocomposição, é lícito às partes plenamente capazes estipular mudanças no procedimento para ajustá-lo às especificidades da causa e convencionar sobre os seus ônus, poderes, faculdades e deveres processuais, antes ou durante o processo.

Parágrafo único. De ofício ou a requerimento, o juiz controlará a validade das convenções previstas neste artigo, recusando-lhes aplicação somente nos casos de nulidade ou de inserção abusiva em contrato de adesão ou em que alguma parte se encontre em manifesta situação de vulnerabilidade.”.

${ }^{11}$ NOGUEIRA, Pedro Henrique Pedrosa. A cláusula geral do acordo de procedimento no projeto do novo CPC (PL 8.046/2010). Novas tendências do processo civil: estudos sobre o projeto do novo Código de Processo Civil. FREIRE, Alexandre; DANTAS, Bruno; NUNES, Dierle; DIDIER JR., Fredie; MEDINA, José Miguel Garcia; FUX, Luiz; CAMARGO, Luiz Henrique Volpe; OLIVEIRA, Pedro Miranda de (org.). Salvador: JusPodivm, 2013, p. 15-26.

${ }^{12}$ Para aprofundamento do estudo sobre os negócios jurídicos processuais, confira-se, por todos: DIDIER JR., Fredie; NOGUEIRA, Pedro Henrique Pedrosa. Teoria dos fatos jurídicos processuais. 2. ed. Salvador: JusPodivm, 2013.
} 
Revista Eletrônica de Direito Processual - REDP. Volume 16. Julho a dezembro de 2015

Periódico Semestral da Pós-Graduação Stricto Sensu em Direito Processual da UERJ

Patrono: José Carlos Barbosa Moreira. ISSN 1982-7636. pp. 58-76

http://www.e-publicacoes.uerj.br/index.php/redp/index

das convenções das partes em matéria processual (quais direitos, quais ônus, quais faculdades e quais deveres poderiam ser convencionados), nem do alcance e dos limites desses negócios processuais (isto é, qual o espectro dessas disposições).

Antes de se aprofundar o estudo desta cláusula geral, importante alerta de faz necessário: não nos parece que o Código tenha caminhado para a "contratualização" ou "privatização" do processo, o que Löic Cadiet identifica, na França, como sendo uma tendência para a superação da crise da Justiça e a duração dos procedimentos naquele país ${ }^{13}$. As partes não se substituem ao legislador quando convencionam sobre suas próprias situações processuais. $\mathrm{O}$ Direito Processual Civil brasileiro passou, apenas, a reconhecer que as partes são as efetivas titulares de determinadas situações processuais e, por essa razão, devem desfrutar de maior poder de regulamentação (disposição lato sensu) sobre as mesmas.

\section{Objeto e limites dos negócios processuais atípicos}

A relação jurídica processual se desenvolve através de um conjunto encadeado de situações processuais em que funcionam como atores as partes, o juiz, os serventuários e os auxiliares do juízo. Como ensina Cândido Rangel Dinamarco "o objeto de cada uma delas é sempre uma conduta - conduta permitida, com ou sem sanções pelo descumprimento (faculdades, ônus), conduta devida (deveres), conduta vedada (sujeição)"14.

O art. 190 do Código de 2015 é claro e expresso ao permitir, às partes, duas ordens distintas de atuação (como reconhecido no Enunciado $257^{15}$ do Fórum Permanente de Processualistas Civis): (i) tanto a realização de adequações no procedimento, para ajustá-lo às especificidades da causa; (ii) quanto a celebração de convenções sobre seus ônus, poderes, faculdades e deveres processuais.

Não nos parece apropriada a interpretação no sentido de que a segunda figura ali prevista (convenção sobre ônus, poderes, faculdades e deveres processuais) teria espaço

\footnotetext{
${ }^{13}$ CADIET, Löic. Los acuerdos procesales en derecho francés: situación actual de la contractualización del proceso y de la justicia en Francia. Civil Procedure Review, v. 4, n. 1, ago.-dez. 2012, p. 03.-35.

${ }^{14}$ DINAMARCO, Cândido Rangel. Op. cit., p. 202.

${ }^{15}$ Enunciado 257 do FPPC: “(art. 190) O art. 190 autoriza que as partes tanto estipulem mudanças do procedimento quanto convencionem sobre os seus ônus, poderes, faculdades e deveres processuais.”.
} 
Revista Eletrônica de Direito Processual - REDP. Volume 16. Julho a dezembro de 2015

Periódico Semestral da Pós-Graduação Stricto Sensu em Direito Processual da UERJ

Patrono: José Carlos Barbosa Moreira. ISSN 1982-7636. pp. 58-76

http://www.e-publicacoes.uerj.br/index.php/redp/index

somente quando necessárias mudanças no procedimento para ajustá-lo às especificidades de uma determinada causa. $\mathrm{O}$ "ajuste às especificidades da causa" nos parece requisito somente da primeira figura (adequação do procedimento), e não da celebração de negócios processuais, tal como reconhecido no Enunciado $258^{16}$ do FPPC.

Como a possibilidade de celebração de negócios processuais atípicos veio consagrada mediante o estabelecimento de uma cláusula geral, não há limites previamente estabelecidos pelo legislador de modo claro, pormenorizado e específico. O art. 190, ao empregar o pronome possessivo seus, indica apenas que o objeto dos negócios processuais deve ser ônus, poderes, faculdades e deveres das partes. Não há identificação, porém, sobre quem é o titular de cada situação ou ato processual lato sensu, se são exclusivamente as partes, ou se o seriam terceiros (julgador, órgão jurisdicional, terceiros interessados, etc.).

O Código de 2015 torna necessária a identificação sobre o titular de cada uma das centenas de situações processuais possíveis: (direito de) ação, demanda, legitimação, contraditório, fundamentação, publicidade, espécies de intervenção de terceiros, respostas, prazo para a prática de ato processual, meio de prova pericial, meios de comunicação dos atos processuais, admissão de prova ilícita, número máximo de testemunhas por parte, valoração das provas, honorários de sucumbência, despesas processuais, duplo grau, efeitos dos recursos, poderes do relator, impenhorabilidade de bem, coisa julgada (formação, limites subjetivos e objetivos, desconsideração, etc.). As partes, o juiz, o Estado, terceiros?

Barbosa Moreira, décadas antes do advento do novo dispositivo, relatou a experiência alemã quanto ao Prozessverträge (contrato processual) e destacou a dificuldade e o esforço dos estudiosos alemães em "estabelecer limites, sem que se haja até agora logrado unanimidade na fixação dos critérios restritivos" 17 .

De acordo com aquela pesquisa, o critério mais utilizado pela doutrina alemã da época era baseado na distinção entre normas processuais cogentes e normas processuais dispositivas, o que não necessariamente apontava uma solução satisfatória. Para outros autores germânicos, a previsibilidade quanto aos efeitos dos atos de disposição, numa convenção processual, deveria

\footnotetext{
${ }^{16}$ Enunciado 258 do FPPC: “(art. 190) As partes podem convencionar sobre seus ônus, poderes, faculdades e deveres processuais, ainda que essa convenção não importe ajustes às especificidades da causa.”.

${ }^{17}$ MOREIRA, José Carlos Barbosa. Op. cit., p. 88.
} 
Revista Eletrônica de Direito Processual - REDP. Volume 16. Julho a dezembro de 2015

Periódico Semestral da Pós-Graduação Stricto Sensu em Direito Processual da UERJ

Patrono: José Carlos Barbosa Moreira. ISSN 1982-7636. pp. 58-76

http://www.e-publicacoes.uerj.br/index.php/redp/index

constituir uma limitação para preservar o dever estatal de prestar uma tutela justa ${ }^{18}$.

Para Miguel Teixeira de Souza, a moldura para a convenção dos atos processuais encontra seus limites na disponibilidade dos efeitos dos atos processuais convencionados ${ }^{19}$.

Leonardo Greco, por seu turno, entende que os limites estariam vinculados a 03 (três) diferentes fatores: (i) disponibilidade do direito material; (ii) igualdade material ou paridade de armas entre as partes; e (iii) preservação da ordem pública processual (observância das garantias fundamentais processuais $)^{20}$. É evidente que esses limites (e alguns outros) foram vislumbrados por Leonardo Greco levando em consideração o Código de 1973, e não o de 2015.

Os dois primeiros limites encontram substrato no texto do art. 190 do novo Código. O caput exige que a causa verse a respeito de direitos que admitam autocomposição. Já o parágrafo único do dispositivo, a seu turno, autoriza o juiz a controlar a validade nas hipóteses de manifesta situação de vulnerabilidade de uma das partes.

A observância das garantias fundamentais do processo, por sua vez, é uma inferência que se faz a partir da presunção de nulidade da convenção que viola princípios constitucionais indisponíveis, segundo Greco ${ }^{21}$. Para o autor, não há espaço para convenção a respeito de ônus, poderes, faculdades e deveres processuais que violem garantias fundamentais como, por exemplo, independência, imparcialidade e competência absoluta, liberdade de acesso à tutela jurisdicional em igualdade de condições, ampla e oportuna utilização de todos os meios de defesa, controle da legalidade e causalidade das decisões judiciais através da fundamentação e celeridade do processo, etc.

Pensamento semelhante é compartilhado por Marcelo Pacheco Machado, que assim afirma: "a transação quanto à técnica processual e a privatização do processo têm limites objetivos no núcleo essencial previsto pelo devido processo legal. É dizer, na necessidade dos princípios do processo serem preservados no seu mínimo essencial" ${ }^{22}$. O autor lembra que a Lei de Arbitragem apresenta vedação similar ao estatuir que as partes poderão escolher, livremente,

\footnotetext{
${ }^{18}$ MOREIRA, José Carlos Barbosa. Op. cit., p. 91-92.

${ }^{19}$ SOUZA, Miguel Teixeira de. Estudos sobre o novo processo civil. Lisboa: Lex, 1997, p. 193.

${ }^{20}$ GRECO, Leonardo. Op. cit., p. 10 e ss.

${ }^{21}$ GRECO, Leonardo. Op. cit., p. 11.

${ }^{22}$ MACHADO, Marcelo Pacheco. A privatização da técnica processual no projeto de novo código de processo civil. In: FREIRE, Alexandre; DANTAS, Bruno; NUNES, Dierle; DIDIER JR., Fredie; MEDINA, José Miguel Garcia; FUX, Luiz; CAMARGO, Luiz Henrique Volpe; OLIVEIRA, Pedro Miranda de (org.). Novas tendências do processo civil: estudos sobre o novo Código de Processo Civil. Salvador: JusPodivm, 2014, p. 349.
} 
Revista Eletrônica de Direito Processual - REDP. Volume 16. Julho a dezembro de 2015

Periódico Semestral da Pós-Graduação Stricto Sensu em Direito Processual da UERJ

Patrono: José Carlos Barbosa Moreira. ISSN 1982-7636. pp. 58-76

http://www.e-publicacoes.uerj.br/index.php/redp/index

as regras de direito que serão aplicadas, desde que não haja violação aos bons costumes e à ordem pública.

Não obstante as lições acima referidas, cabe indagar se o objeto de um negócio processual realmente estaria limitado pelas garantias fundamentais processuais. Seriam elas realmente indisponíveis a ponto de proibir a liberdade das partes para convencionar no sentido de sua mitigação ou, até mesmo, de seu integral afastamento em determinado aspecto pontual? Os direitos fundamentais seriam, a rigor, irrenunciáveis ${ }^{23}$ ? Sendo as partes maiores e capazes, por qual razão não poderiam convencionar estipulando uma limitação às provas, ao contraditório ou, até mesmo, ao direito de demandar sobre determinada relação jurídica de direito material?

Se o intérprete mantiver a mentalidade e a ótica que adotava durante a égide do Código de 1973, provavelmente sua conclusão será sempre no sentido da impossibilidade de celebração do negócio processual ${ }^{24}$, por considerar que o objeto não estaria ao alcance das partes, por ser “indisponível” ou pertencente (também ou exclusivamente) ao juiz, ao Estado ou à sociedade.

Não temos a pretensão de responder, neste breve ensaio, às indagações acima. A identificação sobre a licitude de cada possível objeto de negócio jurídico processual exige reflexão aprofundada, amadurecimento do tema, diálogo doutrinário e maior pesquisa pelos processualistas brasileiros. Essa é uma das importantes missões que os Professores de Direito Processual e os operadores do Direito (advogados, juízes, promotores, etc.) terão ao longo dos próximos anos.

\section{Validade dos negócios processuais atípicos: relação entre os regimes do CPC e do CC}

\footnotetext{
23 É fascinante a polêmica que envolve a possibilidade de renúncia a direito fundamental, inexistindo, evidentemente, uma resposta simples e a priori. Para aprofundamento do tema, confira-se ADAMY, Pedro. Renúncia a direito fundamental. São Paulo: Malheiros, 2011; MARTEL, Letícia de Campos Velho. Indisponibilidade dos direitos fundamentais: conceito lacônico, consequências duvidosas. Espaço Jurídico, v. 11, 2010, p. 334-373; e MARTEL, Letícia de Campos Velho. São os direitos fundamentais disponíveis? Reflexões à luz da teoria dos direitos de Robert Alexy. In: MARTEL, Letícia de Campos Velho (org.). Estudos contemporâneos de direitos fundamentais. Rio de Janeiro/Criciúma: Lumen Juris/UNESC, 2009. v. 2, p. 43-70.

${ }^{24}$ No mesmo sentido manifesta-se Marcelo Machado: "norma do art. 191 deixa muita margem para discussão e para divergências (...). Diminuindo a abrangência do dispositivo, corremos o risco de torná-lo inútil, por sua vez, ao amplia-lá, corremos o risco de aumentarmos os problemas (...). Isso tudo, aliado a grande incerteza que esta norma de conteúdo aberto e de extensão tão duvidosa pode gerar no Judiciário." (MACHADO, Marcelo Pacheco. Op. cit., p. 358).
} 
Revista Eletrônica de Direito Processual - REDP. Volume 16. Julho a dezembro de 2015

Periódico Semestral da Pós-Graduação Stricto Sensu em Direito Processual da UERJ

Patrono: José Carlos Barbosa Moreira. ISSN 1982-7636. pp. 58-76 http://www.e-publicacoes.uerj.br/index.php/redp/index

Qual o regime geral aplicável ao negócio jurídico que promove uma adaptação no procedimento, ou que convenciona a respeito de ônus, poderes, faculdades ou deveres processuais? Submete-se ao regime de atos e negócios jurídicos previstos no Código de Processo Civil ou deve ser analisado a partir das disposições previstas no Código Civil?

Barbosa Moreira, ao tratar das convenções processuais sob a égide do Código de 1973, afirmava que elas deveriam ser regidas por um sistema misto, formado por normas tanto do Código de Processo Civil, quanto do Código Civil ${ }^{25}$.

Fredie Didier Júnior e Pedro Henrique Pedrosa Nogueira compartilham de idêntica conclusão: "Do que se expôs, resulta ser possível cogitar, no direito brasileiro, da sujeição dos atos processuais, e, de modo particular, dos negócios jurídicos processuais a um duplo regime (substancial e processual) em matéria de invalidades"26.

Já segundo Leonardo Greco, em razão da convenção processual referir-se a atos do processo, deve ela submeter-se à forma e ao conteúdo prescritos pela lei processual. E, mesmo que produza efeitos no plano do direito material, o regime deve continuar sendo o processual, mas em concorrência com o sistema de regência do direito material na parte que tratar dos efeitos materiais decorrentes que forem tratados na convenção ${ }^{27}$.

A nosso ver, o fato de a convenção processual tratar de objeto não material não exclui a incidência do regime de validade previsto no Código Civil. A validade de uma convenção processual exige dupla conformidade: deve submeter-se às prescrições tanto do Código de Processo Civil, quanto do Código Civil.

No que tange aos defeitos do negócio processual, a submissão ao critério da dupla conformidade (CPC e CC) exige algumas reflexões.

O parágrafo único do art. 190 do NCPC disciplina que o juiz, ao controlar a validade da convenção - de ofício ou a requerimento das partes - recusará sua aplicação nos casos de nulidade ou de inserção abusiva em contrato de adesão ou em que alguma parte se encontre em manifesta situação de vulnerabilidade.

O sentido da expressão nulidade, neste contexto, abrange as hipóteses de nulidade de

\footnotetext{
${ }^{25}$ MOREIRA, José Carlos Barbosa. Op. cit., p. 93.

${ }^{26}$ DIDIER JR., Fredie; NOGUEIRA, Pedro Henrique Pedrosa. Op. cit., p. 115.

${ }^{27}$ GRECO, Leonardo. Op. cit., p. 13.
} 
Revista Eletrônica de Direito Processual - REDP. Volume 16. Julho a dezembro de 2015

Periódico Semestral da Pós-Graduação Stricto Sensu em Direito Processual da UERJ

Patrono: José Carlos Barbosa Moreira. ISSN 1982-7636. pp. 58-76

http://www.e-publicacoes.uerj.br/index.php/redp/index

pleno direito ou absoluta, e não os casos de nulidade relativa ou de anulabilidade. A possibilidade conferida ao juiz de recusar aplicação de negócio processual em razão de nulidade se restringe aos casos em que a referida nulidade é absoluta, cuja gravidade do vício impede a produção de qualquer efeito, cujas hipóteses estão previstas no art. 166 do Código Civil ${ }^{28}$.

Assim é que o negócio processual independe de forma determinada (art. 188 do CPC/2015 c/c art. 107 do CC). Pode celebrar negócio processual quem tiver capacidade tanto civil, quanto processual (dupla conformidade), sendo necessário, no caso de convenção firmada por advogado, a outorga de poderes específicos pela parte para firmar compromissos (art. 105 do CPC/2015). O objeto do negócio processual deve ser lícito, isto é, atender aos limites do art. 190 do NCPC e o regime de dupla conformidade (CC e CPC), versando sobre ônus, poderes, faculdades e deveres processuais das partes.

As demais situações, que acarretam a anulação de negócio jurídico em geral, não podem ser conhecidas de ofício pelo juiz, sendo incapazes de justificar a recusa de aplicação de negócio processual com fundamento no parágrafo único do art. 190 do $\mathrm{CPC} / 2015$, mesmo quando requeridas pela parte, exceto nos casos de anulabilidade caracterizada por manifesta vulnerabilidade da parte (como pode acontecer em casos como os de coação, estado de perigo ou lesão).

Em outras palavras, o juiz pode recusar a aplicação de negócio jurídico eivado de nulidade absoluta, estando, porém, impedido de recusar a aplicação ao negócio jurídico meramente anulável, exceto quando constatar situação de manifesta vulnerabilidade da parte. $\mathrm{O}$ sentido da norma estatuída no parágrafo único do art. 190 é restritivo, limitando a cognição judicial e a recusa da aplicação do negócio jurídico processual somente nas hipóteses ali delimitadas.

Isto não significa que haja óbice ao conhecimento de pretensões no sentido da desconstituição de negócio jurídico processual anulável. As nulidades relativas e as anulabilidades podem ser arguidas por meio de demanda própria, e não por mero requerimento

\footnotetext{
${ }^{28}$ Código Civil de 2002: “Art. 166. É nulo o negócio jurídico quando: I - celebrado por pessoa absolutamente incapaz; II - for ilícito, impossível ou indeterminável o seu objeto; III - o motivo determinante, comum a ambas as partes, for ilícito; IV - não revestir a forma prescrita em lei; V - for preterida alguma solenidade que a lei considere essencial para a sua validade; VI - tiver por objetivo fraudar lei imperativa; VII - a lei taxativamente o declarar nulo, ou proibir-lhe a prática, sem cominar sanção.”.
} 
Revista Eletrônica de Direito Processual - REDP. Volume 16. Julho a dezembro de 2015

Periódico Semestral da Pós-Graduação Stricto Sensu em Direito Processual da UERJ

Patrono: José Carlos Barbosa Moreira. ISSN 1982-7636. pp. 58-76

http://www.e-publicacoes.uerj.br/index.php/redp/index

ou via incidental no processo em que pretende a aplicação da convenção processual. É necessário manter a coerência e integridade entre os sistemas do $\mathrm{CPC}$ e do $\mathrm{CC}$, tanto na conformação e aplicação do negócio jurídico, quanto no exame de sua validade.

Além do regime das nulidades e anulabilidades do Código Civil, as convenções processuais também se submetem ao regime de invalidades processuais, previsto nos arts. 276 a 283 do Código de Processo Civil de 2015.

Assim é que o controle de validade do negócio, pelo juiz ex officio ou a requerimento da parte, pode ser realizado a qualquer tempo e grau de jurisdição, não se sujeitando à preclusão (parágrafo único do art. $190 \mathrm{c} / \mathrm{c}$ parágrafo único do art. 278 do CPC/2015), observadas as restrições já mencionadas.

Além disso, quando puder decidir o mérito a favor da parte a quem aproveita a decretação da nulidade da convenção processual, o juiz não a pronunciará nem mandará repetir o ato ou suprir-lhe a falta $\left(\operatorname{art.} 282, \S 2^{\circ}\right)$.

\section{Eficácia dos negócios processuais atípicos}

O art. 200 do novo Código repete a regra que já constava do art. 158 do CPC/1973, no sentido da eficácia imediata, como regra geral, dos negócios jurídicos processuais. As manifestações de vontade das partes produzem efeitos de imediato, salvo quando a lei exigir prévia homologação judicial. Como se vê, a homologação pelo juiz tem natureza excepcional e se faz necessária somente quando houver regra clara e específica a exigi-la. Nesse sentido, inclusive, tem-se os Enunciados $133^{29}$ e $261^{30}$ do Fórum Permanente de Processualistas Civis.

A eficácia imediata dos negócios processuais é confirmada, ainda, pelo parágrafo único do art. 190, que revela que o controle das convenções processuais pelo juiz é sempre a posteriori e imitado aos vícios de inexistência ou de invalidade. O juiz somente pode negar aplicação a negócio processual se estiver presente alguma invalidade (vício relativo aos planos da existência ou da validade, abusividade de cláusula ou vulnerabilidade de parte), sendo-lhe vedado negar

\footnotetext{
${ }^{29}$ Enunciado 133 do FPPC: “(art. 190; art. 200, parágrafo único) Salvo nos casos expressamente previstos em lei, os negócios processuais do art. 190 não dependem de homologação judicial.”.

${ }^{30}$ Enunciado 261 do FPPC: “(art. 190; art. 200) O art. 200 aplica-se tanto aos negócios unilaterais quanto aos bilaterais, incluindo as convenções processuais do art.190.”.
} 
Revista Eletrônica de Direito Processual - REDP. Volume 16. Julho a dezembro de 2015

Periódico Semestral da Pós-Graduação Stricto Sensu em Direito Processual da UERJ

Patrono: José Carlos Barbosa Moreira. ISSN 1982-7636. pp. 58-76

http://www.e-publicacoes.uerj.br/index.php/redp/index

aplicação a convenção processual por qualquer outro motivo (v.g., por não ter sido de seu maior agrado o conteúdo do negócio processual).

A análise conjunta dos arts. 190 e 200 revela que o Código de 2015 consagrou uma cláusula geral e uma abertura do sistema processual para o autorregramento da vontade das partes no processo ${ }^{31}$. Este maior espaço para o exercício das liberdades estabelece que a vontade das partes deve ser observada pelo juiz como regra geral, uma vez que a eficácia dos negócios processuais é imediata e independente de homologação judicial, sendo possível o controle judicial somente a posteriori e apenas para o reconhecimento de defeitos relacionados aos planos da existência ou da validade da convenção.

\section{Convenções das partes sobre honorários advocatícios}

Sabe-se que os honorários advocatícios podem ser de duas ordens (art. 22 da Lei 8.906/1994): convencionais (estipulados, no plano do direito material, entre o cliente e o seu advogado) e jurisdicionais (fixados, pelo juiz, em demanda judicial), estes últimos usualmente denominados "honorários de sucumbência" (terminologia equívoca, uma vez que a fixação de verba honorária nem sempre ocorre em razão de sucumbência, isto é, de derrota no fim da demanda, podendo os honorários ser fixados para remunerar o trabalho do advogado já no início da demanda, v.g., honorários para as fases de liquidação ou execução).

Como regra geral, a fixação (arbitramento) dos honorários cabe ao magistrado, conforme alguns parâmetros estabelecidos na lei. À luz, porém, do art. 190 do CPC/2015, é permitido, às partes, convencionar sobre honorários.

Afinal, o pagamento de honorários jurisdicionais é um dever das partes, uma vez que o principal dispositivo relativo aos honorários (art. 85, constante da Seção III) encontra-se inserido dentro do Livro III e, em especial, do Capítulo II (iniciado pelo art. 77), intitulado "dos deveres das partes e de seus procuradores”. Por se tratar — topológica e expressamente — de um dever das partes, é possível a convenção sobre honorários, já que, como analisado anteriormente, o art. 190 é claro ao permitir a convenção sobre ônus, poderes, faculdades e

\footnotetext{
${ }^{31}$ De forma parecida, DIDIER JR., Fredie. Curso de direito processual civil. 17. ed. Salvador: JusPodivm, 2015. v. 1, p. 132-136.
} 
Revista Eletrônica de Direito Processual - REDP. Volume 16. Julho a dezembro de 2015

Periódico Semestral da Pós-Graduação Stricto Sensu em Direito Processual da UERJ

Patrono: José Carlos Barbosa Moreira. ISSN 1982-7636. pp. 58-76

http://www.e-publicacoes.uerj.br/index.php/redp/index

deveres processuais.

Sendo evidente a possibilidade de convenção sobre honorários, cabe-nos analisar seus principais aspectos.

No que tange à eficácia subjetiva da convenção, é importante observar que os honorários jurisdicionais são de titularidade do advogado (art. 85, §14, CPC/2015; art. 23 da Lei 8.906/1994; Súmula 306 do $\mathrm{STJ}^{32}$ e Súmula 135 do $\mathrm{TJRJ}^{33}$ ), o qual pode, voluntariamente, negociar sua repartição com o cliente, caso assim convencionem as partes no momento da celebração do contrato de mandato judicial. O credor dos honorários é o advogado e, o devedor, a parte contrária da demanda. Por essa razão, é necessário que participem da convenção todos os sujeitos da relação obrigacional dos honorários, isto é, todos os advogados que, de acordo com a regra geral, deveriam receber os honorários, bem como todas as partes da demanda que deveriam arcar com o seu custo.

Caso a convenção seja celebrada somente entre as partes, com exclusão dos advogados beneficiários, a princípio a avença não será oponível aos patronos. Não obstante, é possível a adoção do regramento da estipulação em favor de terceiro (art. 436 do CC), a fim de se permitir que uma convenção das partes, sem a participação dos advogados, possa se tornar eficaz em relação aos mesmos na hipótese de ulterior anuência.

Se, durante o curso do processo, uma parte vier a substituir seu advogado, é evidente que a anterior convenção (com o anterior patrono) não será eficaz em relação ao novo profissional, que dela não participou. Não obstante, é facultado, ao novo advogado, anuir à anterior avença sobre honorários, caso eventualmente lhe convenha.

Se houver pluralidade de partes em um polo processual e a convenção abranger apenas um dos litisconsortes (e o advogado), o advogado do outro litisconsorte, que não participou da convenção, estará dela excluído, cabendo ao juiz fixar, em relação a ele, os honorários de acordo com os tradicionais critérios legais (v.g., parágrafos do art. 85). Esse advogado, excluído da convenção, não poderá exigir, do vencido, os honorários convencionados pelos demais.

\footnotetext{
32 Súmula 306 do STJ: “Os honorários advocatícios devem ser compensados quando houver sucumbência recíproca, assegurado o direito autônomo do advogado à execução do saldo sem excluir a legitimidade da própria parte.".

${ }^{33}$ Súmula 135 do TJRJ: "Os honorários advocatícios de sucumbência constituem verba autônoma, de natureza alimentar, podendo ser objeto de requisição específica e independente de requisitório correspondente à condenação devida à parte.".
} 
Revista Eletrônica de Direito Processual - REDP. Volume 16. Julho a dezembro de 2015

Periódico Semestral da Pós-Graduação Stricto Sensu em Direito Processual da UERJ

Patrono: José Carlos Barbosa Moreira. ISSN 1982-7636. pp. 58-76 http://www.e-publicacoes.uerj.br/index.php/redp/index

A obrigação relativa aos honorários não é personalíssima, razão pela qual se transmite aos herdeiros e sucessores, conforme o regramento do Direito Civil, como se depreende do Enunciado 115 do $\mathrm{FPPC}^{34}$.

Quanto ao objeto da convenção, ela pode alterar todos os aspectos da relação obrigacional de pagar honorários.

Pode ser alterada tanto a parte credora - desde que anuam à convenção o devedor, o anterior credor e o novo credor - quanto a parte devedora - desde que anuam o credor, o anterior devedor e o novo devedor.

Pode ser modificado, ainda, o próprio objeto, isto é, os honorários jurisdicionais, que podem ter os seus patamares legais, mínimo e máximo (p.e., art. $85, \S \S 2^{\circ}$ e 11 ), reduzidos ou ampliados (e.g., para menos de $10 \%$ ou para mais de $20 \%$ ), bem como podem ser estipulados em valor "fixo" (líquido e único). É plenamente viável convenção tanto para excluir os honorários quando cabíveis (tratando-se, na realidade, de mera renúncia pelo credor), quanto para, em alguns casos como os dos Juizados Especiais e da ação monitória, dentre outros, permitir a fixação convencional de honorários quando a princípio incabíveis, já que os honorários consistem em dever das partes, sendo-lhes permitido convencionar no sentido da ampliação de seus deveres.

Pode ser modificada, ainda, a base de cálculo prevista, a priori, na lei $\left(\S 2^{\circ}\right.$ e $\S 9^{\circ}$ do art. 85), passando o eventual percentual a incidir sobre a nova base convencionada ( $v . g$., valores da condenação, da causa, do proveito econômico, do bem em disputa, da obrigação principal, etc.). A convenção pode também alterar os critérios que devem ser levados em conta pelo juiz (incisos do $\S 2^{\circ}, \S 8^{\circ}$ e $\S 11$ do art. 85$)$.

Pode a convenção abranger os honorários de todas as atividades possíveis (primeira instância de conhecimento, grau recursal, cumprimento de sentença, processo de execução, liquidação, incidentes, procedimentos especiais, etc.), ou dirigir-se somente a uma determinada fase ou incidente.

É possível, ainda, alteração da própria natureza dos honorários. Como regra geral, tratam-se os honorários de sucumbência (art. 85), antes da prolação da sentença, de mera

\footnotetext{
${ }^{34}$ Enunciado 115 do FPPC: “(art. 190; arts. 109 e 110) O negócio jurídico celebrado nos termos do art. 190 obriga herdeiros e sucessores.".
} 
Revista Eletrônica de Direito Processual - REDP. Volume 16. Julho a dezembro de 2015

Periódico Semestral da Pós-Graduação Stricto Sensu em Direito Processual da UERJ

Patrono: José Carlos Barbosa Moreira. ISSN 1982-7636. pp. 58-76

http://www.e-publicacoes.uerj.br/index.php/redp/index

expectativa de direito condicionada a evento futuro e incerto (qual seja, o resultado da demanda, a vitória da parte e o arbitramento de seu valor pelo juiz). Antes da prolação da sentença, é possível identificar, abstratamente, apenas o an debeatur (natureza da obrigação), estando ainda indefinidos o cui debeatur (credor), o quis debeatur (devedor), o quantum debeatur (valor) e a exigibilidade da obrigação. Por essa razão, a prévia convenção sobre os honorários de sucumbência nasce, em regra, ineficaz. É possível, porém, que a convenção altere a própria natureza desses honorários, tornando-os uma obrigação de direito material (pagamento de quantia certa) que seja certa, líquida e com exigibilidade previamente determinada (v.g., a convenção pode estabelecer que os honorários são devidos independentemente do resultado da demanda, ou a partir de data certa ou de determinado ato ou fase processual).

No que tange ao lugar, a convenção sobre honorários pode ser celebrada fora do processo (v.g., em sede de contrato) ou no âmbito da relação processual (e.g., em audiência, por meio de petição conjunta, etc.).

Relativamente ao tempo, a convenção pode ser pré-processual (antes do início da demanda) ou processual (durante o curso do processo). Relativamente à convenção celebrada no decorrer da demanda, é possível que a pactuação seja anterior à fixação dos honorários pelo juiz - caso em que o magistrado estará obrigado a respeitar as diretrizes constantes da convenção - e, até mesmo, posterior ao arbitramento judicial, caso em que, a rigor, a convenção não será oponível ao juiz, tratando-se de simples transação entre credor e devedor dos honorários, operando mera modificação consensual sobre a obrigação fixada judicialmente.

Finalmente, no que tange aos honorários envolvendo a Fazenda Pública, posicionamonos favoravelmente à possibilidade de convenção, porém com algumas ressalvas.

Sabe-se que nem todos os direitos defendidos pelo Poder Público são indisponíveis, bem como, mesmo nos casos em que o direito seja indisponível, há espaço para a autocomposição (o Enunciado 135 do FPPC $^{35}$ caminha exatamente nesse sentido). Ora, não há como se duvidar que a Fazenda pode celebrar acordo que lhe traga benefício (fático ou jurídico), lhe coloque em posição jurídica de vantagem, ou que minimize prejuízos (de qualquer ordem). Como se admite que a Fazenda transacione em relação ao direito material, é imperiosa a conclusão no sentido da

\footnotetext{
${ }^{35}$ Enunciado 135 do FPPC: “(art. 190) A indisponibilidade do direito material não impede, por si só, a celebração de negócio jurídico processual.”.
} 
Revista Eletrônica de Direito Processual - REDP. Volume 16. Julho a dezembro de 2015

Periódico Semestral da Pós-Graduação Stricto Sensu em Direito Processual da UERJ

Patrono: José Carlos Barbosa Moreira. ISSN 1982-7636. pp. 58-76

http://www.e-publicacoes.uerj.br/index.php/redp/index

possibilidade de celebração de negócios processuais pelo Poder Público (na linha do Enunciado $256^{36}$ do FPPC), desde que observados os mesmos pressupostos, requisitos e limites para a autocomposição de direito material.

Ainda que a regra geral seja a admissibilidade de negócios processuais pela Fazenda, há uma diferencial no que tange à convenção sobre honorários jurisdicionais, que é a identificação sobre o titular desse direito. Como explicado linhas atrás, a eficácia subjetiva da convenção exige que os titulares das posições jurídicas de credor e devedor participem do pacto. Cabe, portanto, indagar: quem é o credor dos honorários nas causas em que a Fazenda é vencedora, bem como quem é o devedor dos honorários quanto o Poder Público é sucumbente? Nas demandas judiciais, o órgão de representação judicial manifesta a vontade da entidade, e não do órgão ou da pessoa natural do procurador. O titular dos honorários é, em regra, a pessoa jurídica de direito público (a União, o Estado, o Município, a autarquia ou a fundação pública de direito público). Ocorre que a lei pode alterar essa regra geral, passando a prever a destinação dos honorários para o órgão, para um fundo ou, até mesmo, para a pessoa dos advogados públicos (art. 85, §19).

Importante lembrar que o direito material também pertence à pessoa jurídica, mas admite-se que a Procuradoria transacione a seu respeito em determinadas situações, desde que observados pressupostos e requisitos que variam conforme o caso (orientação vinculante no âmbito da administração; autorização de superior hierárquico; justificativa pelo procurador do caso concreto, etc.). É por essa razão que entendemos que a convenção sobre honorários deve observar um paralelismo com a composição sobre o direito material, estando sujeita aos seus mesmos pressupostos, requisitos e limites. E, para fins da eficácia subjetiva da convenção, devese analisar, ainda, a lei que regula o ente e a eventual destinação (ou repartição) dos honorários.

\section{REFERÊNCIAS BIBLIOGRÁFICAS}

ADAMY, Pedro. Renúncia a direito fundamental. São Paulo: Malheiros, 2011.

\footnotetext{
${ }^{36}$ Enunciado 256 do FPPC: “(art. 190) A Fazenda Pública pode celebrar negócio jurídico processual.”.
} 
Revista Eletrônica de Direito Processual - REDP. Volume 16. Julho a dezembro de 2015

Periódico Semestral da Pós-Graduação Stricto Sensu em Direito Processual da UERJ

Patrono: José Carlos Barbosa Moreira. ISSN 1982-7636. pp. 58-76

http://www.e-publicacoes.uerj.br/index.php/redp/index

BÜLOW, Oskar. Teoria das exceções e dos pressupostos processuais. 2. ed. (trad. bras. Ricardo Rodrigues Gama). São Paulo: LZN, 2005.

CADIET, Löic. Los acuerdos procesales en derecho francés: situación actual de la contractualización del proceso y de la justicia en Francia. Civil Procedure Review, v. 4, n. 1, ago.-dez. 2012.

CÂMARA, Alexandre Freitas. Lições de direito processual civil. 23. ed. São Paulo: Atlas, 2012. v. 1.

CHIOVENDA, Giuseppe. Instituições de direito processual civil. São Paulo: Bookseller. v. 1.

DIDIER JR., Fredie. Curso de direito processual civil. 17. ed. Salvador: JusPodivm, 2015. v. 1. ; NOGUEIRA, Pedro Henrique Pedrosa. Teoria dos fatos jurídicos processuais. 2.

ed. Salvador: JusPodivm, 2013.

DINAMARCO, Cândido Rangel. Instituições de direito processual civil. 6. ed. São Paulo: Malheiros, 2009. v. 2.

GRECO, Leonardo. Os atos de disposição processual: primeiras reflexões. Revista Eletrônica de Direito Processual, Rio de Janeiro: UERJ, a. 1, v. 1, out.-dez. 2007.

MACHADO, Marcelo Pacheco. A privatização da técnica processual no projeto de novo código de processo civil. In: FREIRE, Alexandre; DANTAS, Bruno; NUNES, Dierle; DIDIER JR., Fredie; MEDINA, José Miguel Garcia; FUX, Luiz; CAMARGO, Luiz Henrique Volpe; OLIVEIRA, Pedro Miranda de (org.). Novas tendências do processo civil: estudos sobre o novo Código de Processo Civil. Salvador: JusPodivm, 2014.

MARTEL, Letícia de Campos Velho. Indisponibilidade dos direitos fundamentais: conceito lacônico, consequências duvidosas. Espaço Jurídico, v. 11, 2010.

São os direitos fundamentais disponíveis? Reflexões à luz da teoria dos direitos de Robert Alexy. In: MARTEL, Letícia de Campos Velho (org.). Estudos contemporâneos de direitos fundamentais. Rio de Janeiro/Criciúma: Lumen Juris/UNESC, 2009. v. 2.

MARTINS, Sandro Gilbert. Processo, procedimento e ato processual: o plano da eficácia. Rio de Janeiro: Elsevier, 2012.

MOREIRA, José Carlos Barbosa. Convenções das partes sobre matéria processual. In: MOREIRA, José Carlos Barbosa. Temas de direito processual: terceira série. São Paulo: São Paulo: Saraiva, 1994. 
Revista Eletrônica de Direito Processual - REDP. Volume 16. Julho a dezembro de 2015

Periódico Semestral da Pós-Graduação Stricto Sensu em Direito Processual da UERJ

Patrono: José Carlos Barbosa Moreira. ISSN 1982-7636. pp. 58-76

http://www.e-publicacoes.uerj.br/index.php/redp/index

NOGUEIRA, Pedro Henrique Pedrosa. A cláusula geral do acordo de procedimento no projeto do novo CPC (PL 8.046/2010). Novas tendências do processo civil: estudos sobre o projeto do novo Código de Processo Civil. FREIRE, Alexandre; DANTAS, Bruno; NUNES, Dierle; DIDIER JR., Fredie; MEDINA, José Miguel Garcia; FUX, Luiz; CAMARGO, Luiz Henrique Volpe; OLIVEIRA, Pedro Miranda de (org.). Salvador: JusPodivm, 2013.

Negócios jurídicos processuais: análise dos provimentos judiciais como atos negociais. Tese de Doutorado. Salvador: UFBA, 2011.

REDONDO, Bruno Garcia. Flexibilização do procedimento pelo juiz e pelas partes no Direito Processual Civil brasileiro. Dissertação de Mestrado. São Paulo: PUC-SP, 2013.

SOUZA, Miguel Teixeira de. Estudos sobre o novo processo civil. Lisboa: Lex, 1997. 